\section{ОЛЬГа КАЗАКЕВИЧ}

Національний педагогічний університет імені М. П. Драгоманова, Київ (Україна)

\footnotetext{
Olga KAZAKEVYCH

National Pedagogical Dragomanov

University, Kyjiv (Ukraine), o.kazakevich@gmail.com
}

\section{ПРОСОПОГРАФІЯ КИЇВСЬКОЇ СТАРОЇ ГРОМАДИ (ДРУГА ПОЛОВИНА ХІХ СТОЛІТТЯ)}

\author{
PROSOPOGRAPHY OF THE OLD KYIV \\ HROMADA (THE LATE XIX CENTURY)
}

Ключевые слова: Киевская Старая Громада, “Комитет вина ХІХ века). В статье представлена попытка построения коллективной биог12 ”, украинское национальное движе- рафии ведущих представителей Киевской Старой Громады, которые входили в ние, национальное строительство. так называемый “Комитет 12”. С помощью метода просопографии выявлены общие черты повседневной жизни, этапов карьеры и профессиональной деятельности, которые объединяли украинских политических и культурных деятелей второй половины XIX века. Проанализировано происхождение, имущественное положение, общественные взгляды, мировозрение и культурно-просветительская деятельность членов Киевской Громады.

Вагомою складовою суспільно-політичного життя Наддніпрянської України другої половини XIX століття була діяльність українських громад. Утворена на початку 1860 -х років Київська Громада стала основним осередком громадівського руху упродовж багатьох десятиліть не зважаючи на перерви у іï діяльності, пов'язані з урядовими утисками українського національного руху. Питання кількісного та персонального складу Київської Громади на сьогодні остаточно не з'ясовано. Проте 3 джерел відомо, що на початку 60-х років XIX століття іiі чисельність сягала сотні осіб, переважно студентів Університету св. Володимира ${ }^{1}$. Стара Київська Громада $70-х$ років XIX ст. налічувала понад 70 осіб, серед яких були педагоги, вчені, письменники, службовці тощо ${ }^{2}$.

Метою даної розвідки є з'ясування соціального портрету діячів Київської Громади на прикладі тих членів Громади, які за свідченнями джерел та на думку дослідників Київської Громади могли входити до так званого "Комітету 12", створенего для заснування закордонного друкованого органу Громади та реалізації закордонної місії М. П. Драгоманова у середині 70-х років XIX століття. Досягнення цієї мети є можливим за допомогою методу просопографії створення колективної біографії групи осіб, об'єднаної спільними інтересами, походженням, діяльністю тощо ${ }^{3}$.

Питання персонального складу “Комітету 12" залишається дискусійним (таб. 1). Достовірно відомо, що до керівного ядра Київської Громади входили В. Б. Антонович, В. Л. Беренштам, М. П. Драгоманов, П. Г. Житецький, М. В. Ковалевський, К. П. Михальчук, О. І. Лоначевський-Петруняка, Ю. Ю. Цвітківський. Крім того, серед членів “Комітету 12" також могли бути Ф. К. Вовк, М. І. Зібер, М. В. Лисенко, В. П. Науменко, Ф. Т. Панченко, І. Я. Рудченко, О. О. Русов, М. П. Старицький, Є. К. Трегубів, П. П. Чубинський, Я. М. Шульгін.

Спроби з абсолютною точністю встановити персональний склад керівного органу Громади навряд чи є виправданими, адже за роки діяльності організації
“Комітет 12”, членство у якому не було формальним, міг зазнавити змін та доповнень. Деякі з попередніх його учасників із тих чи інших причин могли втрачати свій вплив на визначення основних напрямів діяльності товариства.

Переважна більшість громадівців походила 3 родин незаможних дворян, української та польської шляхти, були серед них і вихідці з сімей священика, міщанина, службовців, лікаря, учителя. Показово, що серед членів “Комітету 12" лише Ф. Т. Панченко походив із селянської родини. Значна частина громадівців, зокрема, Ф. К. Вовк, М. П. Драгоманов, П. Г. Житецький, М. В. Ковалевський, М. В. Лисенко, М. П. Старицький народилися на Полтавщині. О. О. Русов та Я. М. Шульгін були уродженцями Києва. Більшість із них належали до одного покоління: станом на 1875 рік середній вік громадівського активу складав 32 роки, коливаючись від 24 до 41 року.

Майже усі громадівці були випускниками Київського Університету св. Володимира, причому значна частина навчалася саме на історико-філологічному факультеті. Ще під час навчання їх об’єднала ідея відстоювання прав українського народу на вільний національний та культурний розвиток. Михайло Старицький згадував, що “національна боротьба, яка розгорталася у храмі науки, піднімала багато проблем, що спали до того часу в нашому мозку ... Ми 3 Лисенком просиджували іноді ночами, міркуючи над національними завданнями, минулим нашої батьківщини та долею-мачухою нашого селянина"11.

М. П. Старицький описав зібрання студентів, яке проводилось українською мовою. Його учасники констатували, що “малоруський народ складає осібну націю, багату всіма даними для культурного розвитку й участі на повний голос у слов'янському концерті..."12. Мету своєї діяльності громадівці вбачали в “піднятті в народі самосвідомості", культурноосвітній діяльності - поширенні освіти серед народу, збиранні етнографічних матеріалів, науковому вивченні української мови, розширенні сфер іiї вжитку, 


\section{Персональний склад “Комітету 12” Київської Старої Громади}

\begin{tabular}{|c|c|c|c|c|c|c|}
\hline \multirow[t]{2}{*}{ № } & \multirow[b]{2}{*}{$\begin{array}{c}\text { ПІБ } \\
\text { діяча Київської Старої Громади }\end{array}$} & \multicolumn{5}{|c|}{ Дослідники } \\
\hline & & 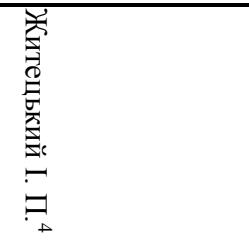 & 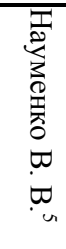 & 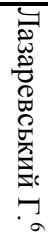 & 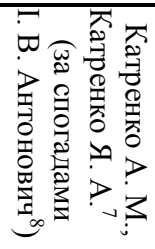 & 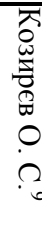 \\
\hline 1 & $\begin{array}{l}\text { Антонович Володимир Боніфатійович (1834(1830)- } \\
1908)\end{array}$ & + & + & + & + & + \\
\hline 2 & Беренштам Вільям Людвигович (1838 (1839)-1904) & + & + & + & + & + \\
\hline 3 & Вовк Федір Кіндратович (1847-1918) & & $?$ & + & & + \\
\hline 4 & Драгоманов Михайло Петрович (1841-1895) & Якщо виключати & + & + & + & + \\
\hline 5 & Житецький Павло Гнатович (1836(1837)-1911) & + & + & + & + & + \\
\hline 6 & Зібер Микола Іванович (1844-1888) & & + & & & + \\
\hline 7 & Ковалевський Микола Васильович (1841-1897) & + & + & + & + & + \\
\hline 8 & Лисенко Микола Віталійович (1842-1912) & + & & + & + & \\
\hline 9 & $\begin{array}{l}\text { Лоначевський-Петруняка, } \\
\text { (Лоначевський) Олександр Іванович (1841-?) }\end{array}$ & $?$ & + & + & + & + \\
\hline 10 & Михальчук Костянтин Петрович (1840(1841)-1914) & + & + & + & + & + \\
\hline 11 & Науменко Володимир Павлович (1852-1919) & + & & & & + \\
\hline 12 & $\begin{array}{l}\text { Панченко Федір Тимофійович } \\
\text { (? - на поч. 1900-х pp. }{ }^{10}\end{array}$ & $?$ & & & + & \\
\hline 13 & Рудченко Іван Якович (1845-1905) & + & & & & \\
\hline 14 & Русов Олександр Олександрович (1847-1915) & & & & + & \\
\hline 15 & Старицький Михайло Петрович (1840-1904) & $?$ & & + & + & \\
\hline 16 & Трегубів Єлисей Купріянович (1848-1920) & $?$ & $?$ & & & \\
\hline 17 & Цвітківський Юрій Юрійович (1843-1913) & + & + & + & + & + \\
\hline 18 & Чубинський Павло Платонович (1839-1884) & + & & & & \\
\hline 19 & Шульгін Яків Миколайович (1851-19011) & & + & & & + \\
\hline
\end{tabular}

здійсненні перекладів на українську мову, підготовці книг для народу та ін. М. П. Драгоманов відзначав, що здійсненні перекладів на українську мову, підготовці книг для народу та ін. М. П. Драгоманов відзначав, що серед тодішньої української молоді були мрії про встановлення на Україні чогось на зразок давньої козацької республіки і про повстання, [...] , але більшість не була так радикальною і більше захоплювалась літературними і національно-художніми інтересами, а також і педагогічними, оскільки всі українці стояли за народну мову в школах""13. Влаштовували громадівці “вечорниці”, учасники яких “зобов’язані були без винятку бути в народному одязі й говорити по-українському" ${ }^{14}$. Навіть страви та напої, на таких вечорах готувалися національні.

Не випадково, одним із виявів самоідентифікації для діячів українського національного руху в другій половині XIX століття став народний одяг. Внутрішнім мотивом використання традиційного сільського вбрання було бажання маніфестувати національну ідентифікацію, усвідомлену на духовному рівні, та продемонструвати демократичну світоглядну позицію. ${ }^{15}$ К. П. Михальчук згадував, що після вимушеного звільнення із гімназії, він ще рік проживав у Житомирі, готуючись до вступу в університет; причому став досить популярним у місті, завдяки своєму публічному виступу з українським твором та незважаючи на поліцейський нагляд, одягався лише в український костюм і демонстративно ходив у ньому по місту, “маючи на меті заманіфестувати цим українство, як особливу національність"16 . Серед членів Київської Громади 60-х років український національний стрій мав символічне значення.

М. В. Лисенко та П. Г. Житецький збираючи етнографічні матеріали у Кременчуцькому повіті також носили народний одяг. Як відмічала Олена Пчілка, “... в козацькому вбранні, 3 мужицькою мовою на устах, звертали на себе велику увагу, се здавалося чудним, непевним. Отже їх перше цуралися, боялися якихсь лихих “паничівських жартів”... Але незабаром побачили, що в сих паничів справді нема нічого пустого на думці, що вони дійсно цікавляться таки піснями, тоді й дівчата й хлопці співали їм. "17

Чимало громадівців прагнули пов'язати свою професійну діяльність із освітою, адже саме у ній вони вбачали шлях національного й соціального визволення народу. Для багатьох 3 них педагогічна каp'єра розпочалася ще на початку 60 -х років XIX ст. у недільних школах. Згодом, у середині 70-х років XIX ст., більшість громадівців була пов'язана 3 педагогічною діяльністю. Члени “Комітету 12" викладали у різних навчальних закладах - Київському кадетському корпусі (В. Л. Беренштам, М. В. Ковалевський, Є. К. Трегубів, Ю. Ю. Цвітківський), Київській Фундуклеївській жіночій гімназії (П. Г. Житецький), Колегії Павла Галагана (П. Г. Житецький, Є. К. Трегубів), 2-й Київській чоловічій гімназії (П. Г. Житецький, В. П. Науменко) у Києві, Петербурзькій військовій гімназії (В. М. Ковалевський), М. В. Лисенко працював учителем гри на фортепіа- 
но, О. I. Лоначевський-Петруняка був директорм Київського ремісничого училища на Подолі. В. Б. Антонович, М. П. Драгоманов та М. І. Зібер викладали в Університеті св. Володимира. Водночас, були серед громадівців й службовці. Зокрема, Ф. Т. Панченко служив військовим лікарем, К. П. Михальчук працював бухгалтером у виробничо -комерційних компаніях, Ф. К. Вовк у 1874-76 pp. був помічником ревізора губернського секретаря, О. О. Русов працював земським статистиком, його педагогічна кар'єра як учителя грецької мови у 1-й Київській гімназії тривала лише декілька років (18721874 рр.) та перервалася через конфлікт 3 керівництвом гімназії ${ }^{18}$. При цьому переважна більшість громадівців займалася науковою або публіцистичною діяльністю. Серед них були визначні історики, філологи, етнографи, економісти, літератори, митці. Олександр Русов згадував, що “Драгоманов запропонував йому взяти участь у складанні збірника українських пісень та дум з історичними коментарями до них. Він й нині стояв на тому ж твердженні, що видання такого збірника буде ще одним зайвим фактом, який доводить існування тієї мови, про яку русифікатори говорили як про щось не існуюче"19.

Ще $з$ початку 60-х років XIX старші представники Київської Громади полемізували 3 російськими вченими стосовно статусу української мови та можливих сфер їі застосування на сторінках періодичних видань, а у подальшому їхні погляди та праця знайшли підтримку серед представників молодшого покоління. У середині 70-х років ХІХ століття О. О. Русов написав підручник "Граматика української мови", який через цензурні утиски опубліковано не було ${ }^{20}$. Як губернський гласний (1898-1901рр.) О. Русов домагався запровадження у школах викладання рідною мовою. ${ }^{21}$ Володимир Науменко полемізував $3 \mathrm{~T}$. Д. Флоринським щодо книжної української мови. Багато зусиль члени Київської Громади докладали для вшанування пам'яті Тараса Шевченка, видання його творів та популяризації творчості Великого Кобзаря. Активна громадська позиція реалізовувалася також через багатогранну організаційну роботу, заснування та участь в роботі наукових та культурномистецьких товариств.

Усі представники “Комітету 12” (можливо, за виключенням Ф. Т. Панченка), були членами Південно-Західного відділу Російського географічного товариства.

З 1882 року багатьох громадівців згуртувала робота навколо часопису “Киевская старина". В. Б. Антонович був одним із ініціаторів заснування та видання журналу та автором майже сотні публікацій на його сторінках. П. Г. Житецький брав участь в організаційній та редакційній роботі журналу, активно займався питаннями передплати і фінансування журналу, обстоюванням інтересів видання перед органами державної влади. В. П. Науменко був редактором часопису із липня 1893 р., а з березня 1902 р. - видавцем. Є. К. Трегубів брав активну участь у виданні "Киевской Старины", особливо під час редагування В. Науменка, він виконував обов'язки коректора, експедитора, скарбника редакції ${ }^{23}$. На сторін- ках журналу у різний час також публікувалися В. Л. Беренштам, Ф. К. Вовк, М. П. Драгоманов, М. В. Лисенко, О. І. Лоначевський, К. П. Михальчук, В. П. Науменко, І. Я. Рудченко, О. О. Русов, М. П. Старицький, Я. М. Шульгін.

Матеріальне становище переважної більшості громадівців можна визначити як середнє. Слід враховувати, що річний дохід представника інтелігенції другої половини ХІХ ст. міг коливатися від 240 крб. на рік, які заробляв земський учитель до 3 тис. крб. щорічного окладу ординарного університетського професора ${ }^{24}$. Можна констатувати, що більшість громадівців належала до матеріально забезпечених верств тодішнього суспільства, проте істотна частина їхніх особистих коштів була спрямована на підтримку української справи.

Особливо значних коштів потребувало фінансування закордонної місії М. П. Драгоманова. Гнат Житецький зазначав, що громадівцями було вирішено видавати Драгоманову на друкування книжок 15001600 карб. на рік і на особисте життя по 1200 карб. (“доцентське утримання”), крім одноразових видатків $^{25}$. Відомо, що Я. М. Шульгін, який одного разу одержав у якості спадщини близько 15 тисяч карбованців, залишив собі невелику частину з цієї суми “за -для наукового удосконалення в європейських землях" (1874-1876 р.), а решту 12 тисяч карбованців віддав до скарбниці Старої Громади на видання, особливо за кордоном, українських книжок ${ }^{26}$.

Дехто з громадівців для отримання додаткового заробітку долучався до викладання приватних уроків (П. Г. Житецький, М. В. Лисенко), а часом це ставало вимушеною небхідністю. За спогадами П. Л. Тучапського, М. В. Ковалевський після повернення з заслання був позбавлений можливості викладати у навчальних закладах, тож займався приватними уроками: "Уроки ці (у заможних київських оселях, переважно, єврейських) оплачували доволі добpe, але все ж не настільки добре, щоб дати можливість і самому Миколі Васильовичу з донькою проіснувати й допомагати Драгоманову."27 Не зважаючи, на те, що під час заслання М. В. Ковалевський підхопив виснажливу невралгію, йдучи на уроки “гористими вулицями Києва у мокречу та заметіль, загорнувшись у свій плед (шуби у нього не було) і не дозволяючи собі витратити зайвий двогривеник на візника"28. Окрім того М. В. Ковалевський декілька разів на рік (здебільшого взимку - на Різдво та на масляну) для збирання грошей здійснював поїздки до Одеси й Харкова у вагоні третього класу.

Упродовж життя, більшість членів “Комітету 12” зазнала переслідувань, які були наслідком репресивної політики Російської імперії, спрямованої проти української національної справи. Так, через політичні погляди не зміг завершити навчання в університеті К. П. Михальчук. У подальшому засновника української діалектології неодноразово заарештовували. На початку 1860-х років до суду викликали В. Б. Антоновича. Поліція проводила дізнання й обшуки у його родичів та знайомих, а за самим Антоновичем було встановлено поліцейський нагляд ${ }^{29}$. У 1862 році до Архангельська було заслано 
П. П. Чубинського. У 1878 році заслання до Пскова зазнав В. Л. Беренштам. У 1879 році до Сибіру було адміністративно заслано М. В. Ковалевського. Наприкінці 70-х років XIX століття за неблагонадійність було звільнено з посади О. І. ЛоначевськогоПетруняку. В 1879 році Я. М. Шульгін був адміністративно засланий на Сибір, як причетний до перевезення 3-за кордону друкарні для Старої Громади ${ }^{30}$, у 1897-1883 рр. він перебував у Єнісейську та Красноярську ${ }^{31}$ Ф. Т. Панченко був заарештований через виявлені у нього галицькі та українські книжки, що складали громадівську власність ${ }^{32}$ у 1886 році. Через положення Емського указу 1876 р., були змушені залишити Україну М. П. Драгоманов та П. П. Чубинський як "невиправні й небезпечні агітатори" "33 . П. П. Чубинський виїхав до столиці Російської імперії, а М. П. Драгоманов емігрував за кордон. Через урядові переслідування у 1879 році емігрував Ф. К. Вовк, а 1880 року через звинувачення в українофільстві до Санкт-Петербургу був змушений виїхати П. Г. Житецький. Через українофільську діяльність у відставку подав Ю. Ю. Цвітківський. Неодноразово потрапляв під слідство О. О. Русов, який врешті-решт у червні 1889 р. разом $з$ дружиною був висланий за межі Херсонської губернії̈. було заарештовано М. В. Лисенка. Вже після розпаду Російської імперії у 1919 році був заарештований більшовиками та розстріляний В. П. Науменко ${ }^{35}$.

Таким чином, метод просопографії дозволяє визначити низку спільних рис у біографіях лідерів Київської Старої Громади. Більшість із них належала до покоління народжених у 30-40-х pp. XIX ст. й походила 3 середовища “середнього прошарку" тодішнього українського суспільства. Вони були випускниками переважно історико-філологічного факультету Університету св. Володимира, які обирали кар'єру викладачів середніх та вищих навчальних закладів або, рідше, службовців. Професійну діяльність громадівці суміщували з написанням наукових праць, присвячених здебільшого українській історії, етнографії, мові й культурі.

Члени Київської Старої Громади організовували та брали участь у діяльності наукових, культурномистецьких товариств, займалися виданням україномовних книг для широкого загалу читачів, полемізували із російськими вченими стосовно статусу української мови та можливих сфер її застосування, використовували будь-які можливості для вивчення та збереження культурної спадщини, розвитку української мови, літератури, театру, музичного мистецтва. Вони залучали молоде покоління до української справи через виховання та особистий життєвий приклад. Практично усі громадівці витрачали власні кошти на розвиток української справи, нерідко нехтуючи при цьому особистими потребами та комфортом власних родин. Але найбільшою мірою об'єднувала громадівців українська ідентичність та прагнення домогтися реалізації прав народу на вільний розвиток.

\section{Reference:}

${ }^{1}$ Katrenko A. M., Katrenko Ya. A. Nacional"no-kul"turna ta politychna diyal"nist" Kyyivs"koyi hromady (60-90-ti roky XIX st.) / A. M. Katrenko, Ya. A. Katrenko. - K., 2003. - S. 44-45.

${ }^{2}$ Tam samo. - S. 85.

${ }^{3}$ Starovojtenko I. Prosopohrafiya: pidxody do traktuvannya zmistu naukovoyi dyscypliny v istoriohrafiyi / I. Starovojtenko // Special"ni istorychni dyscypliny: Pytannya teoriyi ta metodyky. - K.: Instytut istoriyi Ukrayiny NAN Ukrayiny, 2006. - Chyslo13: Ch.1: . - 2006 . - S. 6-27. - C. 7.

${ }^{4}$ Zhytec"kyj I. Ostannij vyyizd M. P. Drahomanova za kordon / I. Zhytec"kyj // Ukrayina. Naukovyj dvoxmisyachnyk ukrayinoznavstva. - 1926. - Kn. 2-3. - C. 34.

${ }^{5}$ Kozyrev O. S. Personal"nyj sklad "komitetu 12-ty" Kyyivs"koyi "Staroyi Hromady" u 1875-1876 rokax / O. S. Kozyrev // Naukovi praci: Naukovo-metodychnyj zhurnal. - T. 62: Istorychni nauky. - Mykolayiv: Mykolayivs"kyj derzhavnyj humanitarnyj universytet im. Petra Mohyly, 2006. Vypusk 49. - S. 23.

6 Arxiv Myxajla Drahomanova. T. 1: Lystuvannya Kyyivs'koyi staroyi hromady z M. Drahomanovym (18701895 rr.). - Varshava: Ukrayins'kyj naukovyj instytut, 1938. - S. 425.

${ }^{7}$ Katrenko A. M., Katrenko Ya. A. Nacional no-kul turna ta politychna diyal'nist' Kyyivs 'koyi hromady (60-90-ti roky XIX st.) / A. M. Katrenko, Ya. A. Katrenko. - K., 2003. C. 117.

${ }^{8}$ Spomyny Iryny Volodymyrivny Antonovych pro M. P. Drahomanova. Zapysav i do druku podav S. Hlushko // Ukrayina. Naukovyj dvoxmisyachnyk ukrayinoznavstva. 1926. - Kn. 4. - C. 128.

${ }^{9}$ Kozyrev O. S. Personal'nyj sklad "komitetu 12-ty" Kyyivs 'koyi "Staroyi Hromady" u 1875-1876 rokax / O. S. Kozyrev // Naukovi praci: Naukovo-metodychnyj zhurnal. T. 62: Istorychni nauky. - Mykolayiv: Mykolayivs 'kyj derzhavnyj humanitarnyj universytet im. Petra Mohyly, 2006. - Vypusk 49. - S. 24.

${ }^{10}$ Tam samo.

${ }^{11}$ Staryc'kyj M. Do biohrafiyi M. V. Lysenka // M. V. Lysenko u spohodax suchasnykiv. - K. : "Muzychna Ukrayina", 1968. - S. 36.

${ }^{12}$ Tam samo. - S. 39.

${ }^{13}$ Drahomanov M. Avtobiohrafichna zamitka // Myxajlo Drahomanov. Avtozhyttyepys. - K. : Lybid', 2009. - C. 8788.

${ }^{14}$ Staryc kyj M. Do biohrafiyi M. V. Lysenka // M. V. Lysenko u spohodax suchasnykiv. - K. : "Muzychna Ukrayina", 1968. - S. 41.

${ }^{15}$ Olijnyk M. Ukrayins`kyj cholovichyj odyah u pobuti mis`koyi intelehenciyi $\mathrm{v}$ druhij polovyni XIX - pershij polovyni XX stolittya / M. Olijnyk // Narodna tvorchist` ta etnolohiya. - 2015. - № 4. - S. 72.

16 Myxal'chuk K. Yz ukraynskoho bыloho. K vospomynanyyam B. S. Poznanskoho / K. Myxal'chuk // Ukraynskaya zhyzn`. - 1914. - № 8-10. - S. 81-82.

${ }^{17}$ Olena Pchilka. Mykola Lysenko (Spohady i dumky) // Mykola Lysenko u spohadax suchasnykiv. - K. : “Muzychna Ukrayina,” 2003. - T. 1. - S. 52.

${ }^{18}$ Raxno O. Ya. O. O. Rusov: shtryxy do biohrafiyi // O. O. Rusov Shhodennyky ta spohady. - Chernihiv : Upravlinnya u spravax presy ta informaciyi, 2011. - C. 7.

${ }^{19}$ Rusov O. O. Kak ya stal chlenom hromadы // O. O. Rusov Shhodennyky ta spohady. - Chernihiv : Upravlinnya u spravax presy ta informaciyi, 2011. - C.172. 
${ }^{20}$ Raxno O. Ya. O. O. Rusov: shtryxy do biohrafiyi // O. O. Rusov Shhodennyky ta spohady. - Chernihiv : Upravlinnya u spravax presy ta informaciyi, 2011. - C.9.

${ }^{21}$ Tam samo. - C.13.

${ }^{22}$ Naumenko V. Reshen ly professorom T. D. Florynskym vopros o knyzhnoj malorusskoj rechy? - 1900. - T. 68. - № 1. - Otd. 1. - S. 125-155.

${ }^{23}$ Paliyenko M. S. "Kievskaya staryna" u hromads komu ta naukovomu zhytti Ukrayiny (kinec' XIX - pochatok XX st.). - K. : Vydavnyctvo "Tempora", 2005. - S. 339.

${ }^{24}$ Kolyada I. Ukrayins 'ka intelihenciya v Rosiyi: suspil'nopolitychna ta social no-kul turna diyal'nist' (druha polovynpolovyna XIX - pochatok XX st.). - K.: Instytut istoriyi Ukrayiny NAN Ukrayiny, 2010. - C. 116-128.

${ }^{25}$ Zhytec kyj I. Ostannij vyyizd M. P. Drahomanova za kordon / I. Zhytec 'kyj // Ukrayina. Naukovyj dvoxmisyachdvoxmisyachnyk ukrayinoznavstva. - 1926. - Kn. 2-3. - C. 36.

${ }^{26}$ Tam samo. - C. 36.

${ }^{27}$ Tuchapskyj P. L. Yz perezhytoho Devyanostыe hodы. Odessa: Hosudarstvennoe Yzdatel'stvo Ukraynd, 1923. C. 16.

${ }^{28}$ Tam samo. - C. 16.

${ }^{29}$ Ul'yanovs 'kyj V. Syn Ukrayiny (Volodymyr AntonovycAntonovych: hromadyanyn, uchenyj, lyudyna) / V. UlUl'yanovs 'kyj // Antonovych V. B. Moya spovid': Vybrani istorychni ta publicystychni tvory. - K. : Lybid', 1995. - S. 44.

${ }^{30}$ Pobirchenko N. S. Biohrafichnyj slovnyk chleniv KyyivKyyivs `koyi Staroyi Hromady // Pobirchenko N. S. PedahPedahohichna i prosvitnyc 'ka diyal'nist' ukrayins 'kyx HrHromad u druhij polovyni XIX - na pochatku XX stolittya (u dvox knyhax). Kn. I. Kyyivs 'ka Hromada / N. S. PobirPobirchenko. - K. : Naukovyj svit, 2000. - S. 306.

${ }^{31}$ Kozyrev O. S. Personal nyj sklad "komitetu 12-ty" KyyiKyyivs "koyi "Staroyi Hromady" u 1875-1876 rokax / O. S. Kozyrev // Naukovi praci: Naukovo-metodychnyj zhurnal. T. 62: Istorychni nauky. - Mykolayiv: Mykolayivs kyj derzderzhavnyj humanitarnyj universytet im. Petra Mohyly, 2006. - Vypusk 49. - S. 26.

${ }^{32}$ Pobirchenko N. S. Biohrafichnyj slovnyk chleniv KyyivKyyivs 'koyi Staroyi Hromady // Pobirchenko N. S. PedahPedahohichna i prosvitnyc 'ka diyal'nist' ukrayins 'kyx HrHromad u druhij polovyni XIX - na pochatku XX stolittya (u dvox knyhax). Kn. I. Kyyivs 'ka Hromada / N. S. PobirPobirchenko. - K. : Naukovyj svit, 2000. - S. 292.

${ }^{33}$ Savchenko F. Zaborona ukrayinstva 1876 roku: Do istoristoriyi hromads 'kyx ruxiv na Ukrayini 1860-1870-x rokiv / F. Savchenko. - X. - K. : Derzhvydav Ukrayiny, 1930. - C. 383.

${ }^{34}$ Raxno O. Ya. O. O. Rusov: shtryxy do biohrafiyi // O. O. Rusov Shhodennyky ta spohady. - Chernihiv : Upravlinnya u spravax presy ta informaciyi, 2011. - C. 12.

${ }^{35}$ Pajkova Ye. V. Volodymyr Naumenko (1852-1919) / Ye. V. Pajkova // Ukrayins kyj istorychnyj zhurnal. - 1998. - № 6. - S. 90 .

Kazakevich Olga. Prosopography of the Old Kyiv Hromada (the late 19 c.). The article demonstrates an attempt to make the collective biography of leading members of the Kyiv Old Hromada. By applying the prosopography method, some common features of the everyday life, curriculum vitae and professional activity, which brought together the Ukrainian political and cultural figures of the late $19 \mathrm{c}$., were revealed. As it is known, the Kyiv Old Hromada was an unofficial association of intellectuals who popularized and promoted the Ukrain- ian language, history and culture both in Russian empire and Europe from 1860s. While the whole Kyiv Old Hromada comprised from 70 to 100 members, only a small part of them were deeply involved in the decision-making process. The were involved in the so-called "The Committee of 12". As far as membership in the Committee was informal, it is rather hard to establish precise list of its members. At different times the Committee included V. Antonovych, V. Berenshtam, F. Vovk, M. Dragomanov, P. Zhytetskiy, M. Ziber, M. Kovalevskiy, M. Lysenko, O. Lonachevskiy, K. Mykhalchuk, V. Naumenko, F. Panchenko, I. Rudchenko, O. Rusov, M. Starytskiy, E. Tregubiv, Ju. Tsvitkivskiy, P. Chubynskiy, J. Shulgin. Most of them belonged to the generation of those born during 1830-40s and descended from the families of commoners, Orthodox clergymen, teachers, civil servants etc. Almost all of them studied at the Historical and Philological department of St. Vladimir's University of Kyiv, which determined their future careers as researchers and teachers. Some of the Kyiv Old Hromada members became known as prominent Ukrainian historians, linguists and publicists; others achieved significant success in the field of music and theater. Thus, during their lifetime most of them had to work hard as teachers. Members of Kyiv Old Hromada from their own funds sponsored numerous artistic events for the promotion of Ukrainian culture, published a scientific journal "Kievskaya Starina", supported publishing of books in Ukrainian language etc. In 1876 the repression campaign against the Kyiv Old Hromada had started in the Russian empire and most of "The Committee of 12" were either exiled or forced to leave their positions in the education sphere. However, the key figures of the Kyiv Old Hromada continued their public activity until the early $20^{\text {th }}$ century.

Key words: prosopography, the Kyiv Old Hromada, "The Committee of 12", the Ukrainian national movement, nation building.

Ольга Казакевич - кандидат історичних наук, доцент кафедри історії та етнополітики, докторант Національного педагогічного університету імені М. П. Драгоманова. Коло наукових інтересів: український начіональний рух другої половини XIX - початку XX століття, формування модерної української нації, біографістика. Автор понад 40 наукових та навчально-методичних публікацій, у тому числі 1 монографіï.

Olga Kazakevych - Ph. D. in History, Associate professor at the Department of history and ethnic policy of the National Pedagogical Dragomanov University. Research interests: Ukrainian nationalism of the late $19^{\text {th }}$ - early $20^{\text {th }}$, modern Ukrainian nation formation processes, biographic studies. The author has more than 40 articles including 1 monograph.

Received: 19-10-2016

Advance Acces Publischer: November 2016

(C) O.Kazakevych, 2016 